\title{
PERBEDAAN DETERMINAN BALITA STUNTING DI PEDESAAN DAN PERKOTAAN DI PROVINSI LAMPUNG
}

\author{
Arie Nugroho* $\diamond$, Sefanadia Putri* \\ *Jurusan Gizi Poltekkes Kemenkes Tanjungkarang \\ $\diamond$ Corresponding Outhor: arienugroho@poltekkes-tjk.ac.id
}

\begin{abstract}
Stunting merupakan indikator malnutrisi kronik yang menggambarkan riwayat kurang gizi dalam jangka waktu lama dan berkaitan dengan adanya proses perubahan patologis. Data menunjukan bahwa prevalensi stunting di wilayah pedesaan lebih tinggi dibandingkan di perkotaan. Penelitian ini bertujuan untuk mengetahui determinan balita Stunting usia $2-5$ tahun di pedesaan dan perkotaan. Penelitian ini termasuk penelitian analitik dengan desain penelitian cross sectional. Subjek yang dijadikan kasus adalah balita stunting usia 2-5 tahun yang terdiri dari 32 balita stunting di pedesaan dan 32 balita stunting di perkotaan. Variabel yang diamati meliputi berat lahir, panjang lahir, tinggi badan ibu, pemberian ASI ekslusif, MP-ASI dini, dan sosial ekonomi. Analisis data dilakukan dengan uji t, mann whitney, uji chi squere dan atau fisher. Hasil penelitian ada perbedaan berat lahir, tinggi badan ibu dan sosial ekonomi di desa dan di perkotaan. Hasil tersebut merekomendasikan agar kegiatan ANC perlu dilakukan secara rutin oleh ibu hamil terkait dengan berat badan lahir serta peran serta Pemerintah daerah untuk meningkatkan status sosial ekonomi warganya.
\end{abstract}

Kata Kunci: Stunting, perkotaan, pedesaan.

\section{LATAR BELAKANG}

Balita stunting adalah balita yang memiliki tinggi badan yang lebih pendek jika dibandingkan dengan balita sesuai umurnya yaitu kurang dari -2SD berdasarkan indeks TB/U menurut standar WHO 2005 (Kemenkes, 2011). Faktor determinan yang dinilai sangat kuat pengaruhnya adalah infeksi dan gizi. Stunting merupakan indikator malnutrisi kronik yang menggambarkan riwayat kurang gizi dalam jangka waktu lama khususnya gizi 1000 Hari Pertama Kehidupan (Nugroho \& Sofyan , 2018).

Stunting merupakan masalah kesehatan masyarakat dimana balita stunting lebih berisiko mengalami PTM di usia dewasa dan mempengaruhi kemampuan kognitif dan perkembangan pada saat balita (Unicef, 2013). Stunting dipengaruhi oleh kekurangan asupan zat gizi makro dan mikro dalam jangka waktu yang lama, selain itu dipengaruhi oleh faktor lingkungan, sosial ekonomi dan intrauterine growth retardation (IUGR) (Monteiro C.A et al, 2010).

Faktor risiko stunting balita usia $0-23$ bulan di Bali, Jawa Barat, dan NTT adalah BBLR, tinggi badan ibu $<150 \mathrm{~cm}$, sanitasi kurang baik, dan pemberian makanan pre- lakteal (Nadiyah dkk, 2014). Determinan stunting utama pada balita 1-3 tahun di Kecamatan Tanjungkarang barat Kota Bandar Lampung adalah Panjang lahir, ASI tidak eksklusif, Pemberian MP ASI dini dan Sosial ekonomi (Nugroho, 2016).

Prevalensi stunting di Indonesia lebih tinggi daripada negara-negara lain di Asia Tenggara, seperti Myanmar (35\%), Vietnam (23\%), dan Thailand (16\%) (MCA-I, 2016). Hasil Riset Kesehatan Dasar tahun 2013 menunjukan Provinsi Lampung memiliki prevalensi balita sangat pendek sebesar 27,6\% dan balita masuk dalam kategori pendek sebesar $15 \%$. Masalah kesehatan masyarakat dianggap prevalensi tinggi bila prevalensi kependekansebesar 30 - 39 persen dan prevalensi sangat tinggi bila $\geq 40$ persen (WHO, 2010). Sehingga berdasarkan hal ini, Provinsi Lampung masuk dalam kategori wilayah dengan prevalensi pendek sangat tinggi. Prevalensi pendek secara nasional tahun 2013 adalah 37,2 persen (Kemenkes, 2013). Berdasarkan hasil Riskesdas 2013, prevalensi balita balita stunting di Indonesia sebesar $37,2 \%$, yang berarti terjadi peningkatan jika dibandingkan tahun 2010 yaitu sebesar 35,6\%. Pada tahun 2010-2013 prevalensi stunting di wilayah pedesaan lebih tinggi dibandingkan di perkotaan yaitu 
sebesar 40,0\% dan wilayah perkotaan sebesar $31,5 \%$, sedangkan pada tahun 2013 di wilayah pedesaan adalah $42,1 \%$, dan wilayah perkotaan sebesar $32,5 \%$ (Kemenkes RI, 2013).

Faktor yang berhubungan dengan status gizi kronis pada balita balita tidak sama antara wilayah perkotaan dan pedesaan, sehingga upaya penanggulangannya harus disesuaikan dengan faktor yang mempengaruhi. Stunting adalah masalah gizi utama yang akan berdampak pada kehidupan sosial dan ekonomi dalam masyarakat (Renyoet dkk, 2016). Kota bandar lampung memiliki prevalensi stunting sebesar 22,3\% termasuk dalam 5 besar prevalensi tertinggi di Provinsi Lampung dan merupakan ibu kota Provinsi Lampung sehingga dianggap dapat menggambarkan wilayah Perkotaan. Sedangkan Kabupaten Pesawaran termasuk 4 besar prevalensi tertinggi yaitu sebesar 26,7\% (PSG, 2016) diharapkan dapat mewakili wilayah pedesaan. Berdasarkan kondisi tersebut peneliti ingin melakukan penelitian mengenai faktor - faktor yang menyebabkan balita Stunting di pedesaan dan perkotaan.

\section{METODE}

Jenis penelitian ini termasuk penelitian analitik dengan desain penelitian cross sectional. Pada desain ini data diambil pada waktu yang sama untuk mengetahui faktorfaktor yang menjadi penyebab balita stunting usia 2 - 5 tahun di pedesaan dan perkotaan. Penyebab yang diteliti meliputi berat lahir, panjang lahir, tinggi badan ibu, pemberian ASI ekslusif, MP-ASI dini, dan sosial ekonomi keluarga. Data terdiri dari data primer dan sekunder yang dikumpulkan menggunakan lembar angket dan lembar observasi.

Pengolahan data hasil penelitian yang telah dikumpulkan dilakukan menggunakan bantuan komputer. Analisis data menggunakan program komputer. Analisis dalam penelitian ini menggunakan independent $t$ test,mann whitney, chi squre dan fisher test.

\section{HASIL}

\section{Analisis Univariat}

Tabel 1: Distribusi Responden Berdasarkan Karakteristik Umur, Pendidikan \& Pekerjaan di Pedesaan \& Perkotaan

\begin{tabular}{lcccc}
\hline \multirow{2}{*}{ Variabel } & \multicolumn{2}{c}{ Pedesaan } & \multicolumn{2}{c}{ Perkotaan } \\
\cline { 2 - 5 } & $\mathrm{f}$ & $\%$ & $\mathrm{f}$ & $\%$ \\
\hline Umur (tahun) & 1 & 3,1 & 2 & 6,2 \\
$\quad<20$ & 16 & 50 & 10 & 31,2 \\
$20-30$ & 13 & 40,6 & 19 & 59,4 \\
$31-40$ & 2 & 6.2 & 1 & 3,1 \\
$>40$ & & & & \\
Pendidikan & 3 & 9,4 & 2 & 6,2 \\
Tidak pernah sekolah & 2 & 6,2 & - & - \\
Tidak tamat SD & - & - & 6 & 18,8 \\
Tamat SD & 11 & 34,4 & 8 & 25 \\
SMP & 14 & 43,8 & 14 & 43,8 \\
SMA & 2 & 6,2 & 2 & 6,2 \\
PT & & & & \\
Pekerjaan Ibu & 3 & 9,4 & 2 & 6,2 \\
Pedagang/wiraswasta & 2 & 6,2 & 3 & 9,4 \\
Karyawan & 2 & 6,2 & 1 & 3,1 \\
PNS/ TNI/POLRI & 25 & 78,1 & 26 & 81,2 \\
IRT & & & &
\end{tabular}

Berdasarkan tabel di atas setengah responden di pedesaan berumur $20-30$ tahun sekitar 50\%. Umur ibu minimum 19 tahun maksimum 43 tahun rata- rata 29,96 tahun SD $+6,11$, dengan pendidikan adalah Sekolah Menengah Atas (SMA) yaitu sebanyak 43,8 \%, sedangkan pekerjaan responden sebagian besar adalah ibu rumah tangga $(78,1 \%)$.

Pada responden di perkotaan lebih dari setengah responden berumur $31-40$ tahun sekitar 59,4\%. Umur ibu minimum 20 tahun maksimum 41 tahun rata- rata 32 tahun SD + 4,91 dengan pendidikan adalah Sekolah Menengah Atas (SMA) yaitu sebanyak 43,8 $\%$, sedangkan pekerjaan responden sebagian besar adalah ibu rumah tangga. 
Tabel 2: Distribusi Responden Berdasarkan Berat Lahir, Panjang Lahir, Tinggi Badan Ibu, ASI eksklusif, MP-ASI dini dan Sosial Ekonomi

\begin{tabular}{lcccc}
\hline \multirow{2}{*}{ Variabel } & \multicolumn{2}{c}{ Pedesaan } & \multicolumn{2}{c}{ Perkotaan } \\
\cline { 2 - 5 } & f & $\%$ & f & $\%$ \\
\hline Berat Lahir & & & & \\
$\quad$ Rendah & 10 & 31,2 & 9 & 28,1 \\
$\quad$ Normal & 22 & 68,8 & 23 & 71,9 \\
Panjang Lahir & & & & \\
$\quad$ Pendek & 12 & 37,5 & 8 & 25 \\
$\quad$ Normal & 20 & 62,5 & 24 & 75 \\
Tinggi Badan Ibu & & & & \\
$\quad$ Pendek & 22 & 68,8 & 14 & 43,8 \\
$\quad$ Normal & 10 & 31,2 & 18 & 56,2 \\
ASI Ekslusif & & & & \\
$\quad$ Tidak ASI Ekslusif & 23 & 71,9 & 16 & 50 \\
$\quad$ ASI Ekslusif & 9 & 28,1 & 16 & 50 \\
MP- ASI dini & & & & \\
$\quad$ MP-ASI dini & 23 & 71,9 & 16 & 50 \\
$\quad$ MP- ASI tidak dini & 9 & 28,1 & 16 & 50 \\
Sosial ekonomi & & & & \\
$\quad$ < UMR & 26 & 81,2 & 24 & 75 \\
$\quad$ UMR & 6 & 18,8 & 8 & 25 \\
\hline
\end{tabular}

Berdasarkan tabel di atas untuk didaerah pedesaan berat badan lahir responden paling rendah adalah 2100 gr sedangkan paling berat adalah 3100 gr dengan rata - rata berat badan lahir yaitu 2633 gr $+254,37$. Panjang lahir responden paling pendek yaitu $41 \mathrm{~cm}$ dan yang paling tinggi yaitu $51 \mathrm{~cm}$ dengan rata- rata panjang lahir yaitu $47,21 \mathrm{~cm} \mathrm{SD} \pm 2,15$. Untuk sosial ekonomi yang di wakili dengan pendapatan selama satu bulan diperoleh bahwa responden di wilayah pedesaan memiliki pendapatan mimimum Rp 400.000 / bulan dan memiliki pendapatan paling besar Rp. 3.800.000 dengan rata rata penghasilan perbulan Rp. 1.414.000.

Sedangkan untuk wilayah perkotaan berat badan lahir responden paling rendah adalah 2200 gr sedangkan paling berat adalah 3300 gr dengan rata - rata berat badan lahir yaitu 2765 gr $+281,2$. Panjang lahir responden paling pendek yaitu $43 \mathrm{~cm}$ dan yang paling tinggi yaitu $50 \mathrm{~cm}$ dengan ratarata panjang lahir yaitu $47,46 \mathrm{~cm} \mathrm{SD} \pm 1,72$. Untuk sosial ekonomi yang di wakili dengan pendapatan selama satu bulan diperoleh bahwa responden di wilayah perkotaan memiliki pendapatan mimimum $\mathrm{Rp}$ 1.000.000 / bulan dan memiliki pendapatan paling besar Rp. 3.800 .000 dengan rata rata penghasilan perbulan Rp. 1.896.900.

Berdasarkan tabel di atas juga diketahui bahwa responden memiliki Berat Lahir normal yaitu $68,8 \%$ untuk wilayah pedesaan dan $71,9 \%$ untuk wilayah perkotaan, panjang lahir normal yaitu $62,5 \%$ untuk wilayah pedesaan dan $75 \%$ untuk wilayah perkotaan, Tinggi badan ibu umumnya pendek $68,8 \%$ pada wilayah pedesaan dengan tinggi badan ibu paling pendek $140 \mathrm{~cm}$ dan paling tinggi $162 \mathrm{~cm}$ dengan rata- rata tinggi badan ibu $150,5 \mathrm{~cm}$ $\pm 4,87$. Pada wilayah perkotaan lebih dari separuh ibu responden memiliki tinggi badan normal yaitu 56,2\% dengan tinggi badan ibu paling pendek $145 \mathrm{~cm}$ dan paling tinggi 177 $\mathrm{cm}$ dengan rata- rata tinggi badan ibu 153,7 $\mathrm{cm} \pm 6,96$.

Pemberian ASI ekslusif dan mendapatkan MP-ASI dini lebih tinggi di perkotaan yaitu $50 \%$ dibanding pedesaan. Seluruh responden baik didesa dan dikota memiliki pendapatan/ sosial ekonomi dibawah UMP (Upah Minimum Provinsi Lampung tahun 2018 ) yaitu sebesar Rp. 2.074.000.

\section{Analisis Bivariat}

Tabel 3: Distribusi Perbedaan Rata-rata Berat Lahir Balita Stunting di Pedesaan dan Perkotaan

\begin{tabular}{ccccc}
\hline Wilayah & Mean & SD & p value & $\mathrm{n}$ \\
\hline Pedesaan & 2633 & 254,37 & \multirow{2}{*}{0,058} & $\frac{32}{32}$ \\
\hline Perkotaan & 2765 & 281,25 & & 32 \\
\hline
\end{tabular}

Berdasarkan tabel di atas diperoleh rata- rata berat lahir balita untuk wilayah pedesaan yaitu 2633 gr dengan standar deviasi 254,37g, sedangkan untuk balita wilayah perkotaan rata- rata berat lahir adalah 2765 gr dengan standar deviasi $281,2 \mathrm{~g}$. Hasil uji t diperoleh nilai $\mathrm{p}=0,058$. Berarti ada perbedaan yang antara berat lahir anak stunting di desa dan di perkotaan. Dimana rata- rata berat lahir di desa lebih rendah dibanding diperkotaan dengan nilai rata- rata berat lahir yaitu $2633 \mathrm{~g} \pm 254,37$ untuk wilayah pedesaan dan $2765 \mathrm{~g}+281,2$ untuk wilayah perkotaan. 
Tabel 4: Distribusi Perbedaan Rata-rata Panjang Lahir Balita Stunting di Pedesaan dan Perkotaan

\begin{tabular}{ccccc}
\hline \multicolumn{1}{c}{ Wilayah } & Mean & SD & p value & $\mathrm{n}$ \\
\cline { 1 - 3 } Pedesaan & 47,21 & 2,15 & \multirow{2}{*}{0,634} & $\frac{32}{32}$ \\
\cline { 1 - 3 } Perkotaan & 47,46 & 1,72 & & 3 \\
\hline
\end{tabular}

Berdasarkan tebel di atas diketahui bahwa subjek yang tinggal di pedesaan yang lahir dengan panjang lahir pendek lebih besar dibandingkan subjek yang tinggal di perkotaan. Rata- rata panjang lahir balita untuk wilayah pedesaan yaitu $47,21 \mathrm{~cm}$ dengan standar deviasi $2,15 \mathrm{~cm}$, sedangkan untuk balita wilayah perkotaan rata- rata panjang lahir adalah 47,46 $\mathrm{cm}$ dengan standar deviasi $1,72 \mathrm{~cm}$. Hasil uji mann whitey diperoleh nilai $\mathrm{p}=0,634$. Berarti tidak ada perbedaan yang antara panjang lahir anak stunting di desa dan di perkotaan.

Tabel 5: Distribusi Perbedaan Rata-rata Tinggi Badan Ibu Balita Stunting di Pedesaan dan Perkotaan

\begin{tabular}{|c|c|c|c|c|}
\hline Wilayah & Mean & SD & $p$ value & $\mathrm{n}$ \\
\hline Pedesaan & 150,5 & 4,87 & \multirow{2}{*}{0,057} & 32 \\
\hline Perkotaan & 153,7 & 6,96 & & 32 \\
\hline
\end{tabular}

Berdasarkan tabel di atas diktehui terdapat perbedaan tinggi badan antara ibu subjek yang tinggal di kota dan didesa dimana ibu subjek yang tinggal didesa lebih banyak yang memiliki tinggi badan pendek dibandingkan dengan yang tinggal di pekotaan. Rata-rata tinggi badan ibu balita untuk wilayah pedesaan yaitu $150,5 \mathrm{~cm}$ dengan standar deviasi $4,87 \mathrm{~cm}$, sedangkan untuk ibu balita wilayah perkotaan rata- rata tinggi badan adalah 153,7 cm dengan standar deviasi $6,96 \mathrm{~cm}$. Hasil uji mann whitey diperoleh nilai $\mathrm{p}=0,057$. Berarti ada perbedaan yang antara tinggi badan anak stunting di desa dan di perkotaan. Dimana rata-rata tinggi badan ibu anak balita stunting di desa lebih pendek dibanding wilayah perkotaan.
Tabel 6: Distribusi Perbedaan ASI Ekslusif pada Anak Stunting di Pedesaan dan Perkotaan

\begin{tabular}{|c|c|c|c|}
\hline \multirow{2}{*}{ Variabel } & Desa & Kota & \\
\hline & $\%$ & $\%$ & $-p v$ \\
\hline $\begin{array}{l}\text { Tidak ASI } \\
\text { ekslusif }\end{array}$ & 2371,9 & $16 \quad 50$ & \\
\hline ASI eksklusif & $\begin{array}{ll}9 & 28,1 \\
\end{array}$ & $16 \quad 50$ &, 124 \\
\hline Jumlah & $32 \quad 100$ & $32 \quad 100$ & \\
\hline
\end{tabular}

Berdasarkan Tabel di atas diketahui bahwa subjek yang tinggal di pedesaan lebih banyak yang tidak mendapat ASI ekslusif yaitu sebesar 71,9\% dibandingkan dengan subjek yang tinggal di perkotaan $50 \%$. Hasil analisis uji beda antara pemberian ASI ekslusif di desa dan kota diperoleh p-value 0,124, maka dapat disimpulkan tidak ada perbedaan pemberian ASI ekslusif pada anak stunting yang tinggal di pedesaan dengan yang tinggal di perkotaan.

Tabel 7: Perbedaan MP-ASI Dini pada Anak Stunting di Pedesaan dan Perkotaan

\begin{tabular}{lccccc}
\hline \multirow{2}{*}{ Variabel } & \multicolumn{2}{c}{ Desa } & \multicolumn{2}{c}{ Kota } & \multirow{2}{*}{ v value } \\
\cline { 2 - 5 } & $\mathrm{f}$ & $\%$ & $\mathrm{f}$ & $\%$ & \\
\hline MPASI dini & 23 & 71,9 & 16 & 50 & \\
\hline $\begin{array}{l}\text { Tidak } \\
\text { MPASI dini }\end{array}$ & 9 & 28,1 & 16 & 50 & 0,124 \\
\hline Jumlah & 32 & 100 & 32 & 100 & \\
\hline
\end{tabular}

Berdasarkan tabel di atas diktehui bahwa subjek yang tinggal dipedesaan lebih banyak mendapat MP-ASI dini yaitu sebesar $71,9 \%$ dibandingkan dengan subjek yang tinggal di perkotaan 50\%. Hasil analisis uji beda antara pemberian MP-ASI dini di desa dan kota diperoleh p-value 0,124, maka dapat disimpulkan tidak ada perbedaan pemberian MP-ASI dini pada anak stunting yang tinggal di pedesaan dengan yang tinggal di perkotaan. 
Tabel 8: Distribusi Perbedaan Rata-rata Sosial Ekonomi Keluarga Balita Stunting di Pedesaan dan Perkotaan

\begin{tabular}{ccccc}
\hline Wilayah & Mean & SD & p value & $\mathrm{n}$ \\
\hline Pedesaan & 1.414 .000 & 8433 & \multirow{2}{*}{0,0001} & $\frac{32}{32}$ \\
\hline Perkotaan & 1.896 .900 & 5970 & & \\
\hline
\end{tabular}

Berdasarkan tabel di atas Rata- rata sosial ekonomi (pendapatan) untuk wilayah pedesaan yaitu $\mathrm{Rp} 1.414 .000$ dengan standar deviasi Rp 84.330, sedangkan untuk sosial ekonomi wilayah perkotaan rata- rata $\mathrm{Rp}$ 1.896.900 dengan standar deviasi Rp 59.700. Hasil uji mann whitey diperoleh nilai $\mathrm{p}=$ 0,001 . Berarti ada perbedaan antara sosial ekonomi keluarga anak stunting di desa dan di perkotaan. Dimana sosial ekonomi anak balita stunting di desa lebih rendah pendapatannya dibanding wilayah perkotaan.

\section{PEMBAHASAN}

\section{Berat Lahir}

Hasil penelitian menunjukan ada perbedaan berat lahir anak stunting yang tinggal di desa dengan yang tinggal di perkotaan. Dimana berat lahir anak stunting di pedesaan lebih rendah dibanding yang tinggal diperkotaan.

Stunting merupakan gangguan pertumbuhan linier yang diunjukkan dengan tinggi badan menurut umur $<-2$ standar deviasi dari median tinggi badan menurut umur berdasarkan standar populasi yang dijadikan referensi. Stunting pada anak usia 2 tahun berawal dari ibu hamil kurang gizi yang selanjutnya akan beresiko untuk melahirkan bayi dengan berat lahir rendah yaitu <2500 gr. Beberapa teori menyatakan berat lahir rendah merupakan faktor utama terjadinya stunting ada baduta. Stunting juga disebabkan praktik pemberian makan yang buruk, kualitas makanan tidak baik, serta infeksi. Selain itu, pelayanan kesehatan yang optimal, akses terhadap air bersih, dan sanitasi juga berpengaruh. Secara umum penyebab utama stunting adalah retardasi pertumbuhan intrauteri, asupan gizi yang tidak mencukupi, dan penyakit infeksi selama awal kehidupan terkait dengan pola asuh ibu (Black et al, 2013)

Hasil penelitan Oktarina \& Trini Sudiarti (2013) menyatakan bahwa salah satu penyebab balita stunting di pulau sumatra yaitu berat lahir, dimana balita yang memiliki berat lahir kurang mempunyai risiko 1.31 kali mengalami stunting dibandingkan dengan balita berat lahir normal. Prevalensi kejadian stunting pada balita usia 24-59 bulan di Provinsi Aceh, Sumatera Utara, Sumatera Selatan, dan Lampung adalah 44.1\%. Lebih dari seperempat balita memiliki berat lahir rendah. Penelitian Simanjuntak tahun 2011 yang dilaksanakan di Sulawesi juga menunjukkan bahwa anak dengan berat lahir kurang dari $3000 \mathrm{~g}$ memiliki risiko menjadi stunting 1.3 kali dibandingkan anak dengan berat lahir lebih dari atau sama dengan 3000 gram.

Berat lahir merupakan prediktor kuat terhadap penentuan ukuran tubuh di kemudian hari. Hal ini karena pada umumnya bayi yang mengalami Intra Uterine Growth Retardation (IUGR) tidak dapat mengejar pertumbuhan ke bentuk normal selama masa tumbuh kembangnya. Oleh karena itu peran tenaga kesehatan untuk mengupayakan ibu hamil melakukan ANC merupakan komponen utama dalam hal pencegahan kejadian stunting terkait dengan berat dan panjang lahir bayi.

\section{Panjang lahir}

Hasil penelitian menunjukan tidak ada perbedaan panjang lahir anak stunting yang tinggal di desa dengan yang tinggal di perkotaan. Bila dilihat berdarkan angka panjang lahir anak stunting di desa lebih pendek dibanding anak stunting yang tinggal diperkotaan.

Panjang badan lahir pendek merupakan salah satu faktor risiko stunting pada balita. Panjang badan lahir pendek bisa disebabkan oleh faktor genetik yaitu tinggi badan orang tua yang pendek, maupun karena kurangnya pemenuhan zat gizi pada masa kehamilan (Yupi, 2004). Panjang badan lahir pendek pada anak menunjukkan kurangnya zat gizi yang diasup Ibu selama masa kehamilan, sehingga pertumbuhan janin tidak optimal yang mengakibatkan bayi yang lahir 
memiliki panjang badan lahir pendek (Anugraheni, Kartasurya. 2012; Rahayu, Sofyaningsih, 2011).

Panjang badan lahir berkaitan erat dengan tinggi badan orang tua. Ibu dengan tinggi badan pendek lebih berpeluang utntuk melahirkan anak yang pendek pula. Penelitian di Mesir menunjukkan bahwa anak yang lahir dari Ibu dengan tinggi badan kurang dari $150 \mathrm{~cm}$ lebih berisiko untuk tumbuh stunting (Zottarelli et al, 2007). Penelitian di Semarang menunjukkan bahwa tinggi badan Ibu dan ayah yang pendek merupakan faktor risiko stunting pada anak usia 12-36 bulan (Candra , 2011; Nasikhah, 2012).

Penelitian di Pati yang menunjukkan hasil bahwa panjang badan lahir merupakan faktor risiko kejadian stunting pada anak usia 12-36 bulan (Anugraheni \& Kartasurya. 2012). Penelitian di Indramayu yang menunjukkan hasil bahwa anak yang lahir dengan panjang badan dibawah persentil -10 lebih berisiko tumbuh stunting. Bayi dengan panjang badan lahir pendek berpeluang lebih tinggi untuk tumbuh pendek dibanding anak panjang badan lahir normal (Kusharisupeni, 2002; Kusharisupeni. 2003).

Anak dengan panjang badan lahir pendek menunjukkan kurangnya gizi yang diasup Ibu selama masa kehamilan, sehingga pertumbuhan janin tidak optimal yang mengakibatkan bayi yang lahir memiliki panjang badan lahir yang rendah (Kusharisupeni, 2002). Faktor asupan dan penyakit memegang peranan yang menentukan apakah anak yang lahir dengan panjang badan lahir rendah akan tetap stunting selama masa hidupnya atau berhasil mencapai catch-up grow yang maksimal (Kiely et al, 2013) Anak yang lahir dengan panjang badan lahir pendek memang lebih berisiko untuk tumbuh stunting dibanding anak yang lahir dengan panjang badan normal, tetapi selama anak tersebut mendapatkan asupan yang memadai dan terjaga kesehatannya, maka kondisi panjang badan lahir yang pendek dapat dikejar dengan pertumbuhan seiring bertambahnya usia anak. Oleh karena itu kegiatan ANC perlu dilakukan secara rutin oleh ibu hamil terkait dengan panjang lahir yang berhubungan dengan kejadian stunting.

\section{Tinggi Badan Ibu}

Hasil penelitian menyimpulkan ada perbedaan tinggi badan ibu anak stunting yang tinggal di desa dengan yang tinggal di perkotaan. Dimana tinggi badan ibu anak stunting di desa lebih pendek dibanding tinggi badan ibu anak stunting yang tinggal diperkotaan.

Tinggi badan merupakan salah satu bentuk dari ekspresi genetik, dan merupakan faktor yang diturunkan kepada anak serta berkaitan dengan kejadian stunting. Anak dengan orang tua yang pendek, baik salah satu maupun keduanya, lebih berisiko untuk tumbuh pendek dibanding anak dengan orang tua yang tinggi badannya normal. Orang tua yang pendek karena gen dalam kromosom yang membawa sifat pendek kemungkinan besar akan menurunkan sifat pendek tersebut kepada anaknya. Tetapi bila sifat pendek orang tua disebabkan karena masalah nutrisi maupun patologis, maka sifat pendek tersebut tidak akan diturunkan kepada anaknya.

Hasil penelitan Oktarina \& Sudiarti pada (2013) menyatakan bahwa salah satu penyebab balita stunting di pulau sumatra yaitu tinggi badan ibu. Ibu yang memiliki tinggi badan pendek beresiko 1.36 kali untuk memiliki balita stunting dibandingkan dengan ibu yang memiliki tinggi badan normal. Penelitian di Cina menunjukkan adanya hubungan antara tinggi badan ibu dengan kejadian balita stunting. Tinggi badan ibu $<155 \mathrm{~cm}$ lebih berisiko memiliki anak stunting (Yang et al, 2010).

Terdapat hubungan yang positif dan signifikan antara tinggi badan ibu $<150 \mathrm{~cm}$ dengan stunting pada anak usia $0-23$ bulan di Jawa Barat, Bali, dan NTT. Faktor risiko stunting anak usia $0-23$ bulan di Bali, Jawa Barat, dan NTT adalah BBLR, tinggi badan ibu $<150 \mathrm{~cm}$, sanitasi kurang baik, dan pemberian makanan pre-lakteal (Nadiyah dkk, 2014).

Tinggi badan ibu yang pendek berisiko 1,3 kali memiliki balita stunting dibandingkan dengan dengan ibu yang memiliki tinggi badan yang tinggi Bila orang 
tua pendek akibat kekurangan zat gizi atau penyakit, kemungkinan anak dapat tumbuh dengan tinggi badan normal selama anak tidak terpapar faktor risiko lain (Dewey \& Mayers, 2011).

Penelitian kohor di Jawa Barat menunjukkan bahwa pertumbuhan linear lebih ditentukan oleh lingkungan saat pra kelahiran daripada faktor-faktor pasca kelahiran. Lingkungan pra kelahiran yang dimaksud diantaranya adalah pertumbuhan saat masa janin yang indikatornya dapat dilihat dari berat badan saat lahir $(\mathrm{p}=0.000)$. Postur tubuh ibu juga mencerminkan tinggi badan ibu dan lingkungan awal yang akan memberikan kontribusi terhadap tinggi badan anak sebagai faktor independen. Namun demikian, masih banyak faktor lingkungan yang memengaruhi tinggi badan anak (Taguri et al. 2008).

Kebanyakan BBLR disebabkan oleh faktor dari ibu, faktor terbesar yaitu anemia saat kehamilan (67\%). Faktor dari kehamilan sendiri, faktor paling besar adalah komplikasi saat kehamilan (22\%), sedangkan faktor lain yaitu genetik hanya sebesar 7\% (Asiyah et al. 2010).

Tinggi badan ibu kurang dari $150 \mathrm{~cm}$ menjadi faktor risiko stunting pada anak usia $0-23$ bulan $(\mathrm{OR}=1.77$; 95\%CI:1.20-2.59, $\mathrm{p}<0.005)$. Menurut Depkes RI (2010), di Indonesia, prevalensi anak balita pendek dari kelompok ibu yang pendek $(<150 \mathrm{~cm})$ adalah $46.7 \%$, sedangkan prevalensi balita pendek dari kelompok ibu yang tinggi $(>150 \mathrm{~cm})$ adalah $34.8 \%$. Ini menjadi alasan penting anak perempuan menjadi target penting dalam perbaikan stunting hingga generasi selanjutnya.

Banyak faktor yang mempengaruhi stunting, diantaranya adalah panjang badan lahir, status ekonomi keluarga, tingkat pendidikan dan tinggi badan orang tua. Panjang badan lahir pendek bisa disebabkan oleh faktor genetik yaitu tinggi badan orang tua yang pendek, maupun karena kurangnya pemenuhan zat gizi pada masa kehamilan. Akan tetapi walaupun anak terlahir dari orangtua yang pendek tetapi selama anak tersebut mendapatkan asupan yang memadai dan terjaga kesehatannya, maka kondisi panjang badan lahir yang pendek dapat dikejar dengan pertumbuhan seiring bertambahnya usia anak (WHO, 2016).

\section{Pemberian ASI Tidak Eksklusif}

Hasil penelitian menyimpulkan tidak ada perbedaan pemberian ASI ekslusif pada anak stunting yang tinggal di desa dengan yang tinggal di perkotaan.

Beberapa literatur menyatakan bahwa stunting dipengaruhi oleh riwayat pemberian ASI eksklusif dan penyakit infeksi, seperti diare dan Infeksi Saluran Pernafasan Akut (ISPA). Kebutuhan zat gizi pada usia 0-6 bulan dapat dipenuhi dari ASI. Anak yang tidak mendapatkan ASI eksklusif berisiko lebih tinggi untuk kekurangan zat gizi yang diperlukan untuk proses pertumbuhan. Begitu juga anak yang mengalami infeksi rentan terjadi status gizi kurang. Anak yang mengalami infeksi jika dibiarkan maka berisiko terjadi stunting. ASI eksklusif dapat menurunkan risiko kejadian stunting, karena kandungan kalsium pada ASI mempunyai bioavailabilitas yang tinggi sehingga dapat diserap dengan optimal terutama dalam fungsi pembentukan tulang anak (Horta et al, 2007; Susilowati et al, 2010)

Penelitian di Nepal tahun 2012 menyatakan pemberian ASI ekslusif berhubungan dengan kejadian stunting dimana anak yang tidak ASI ekslusif beresiko 6,9 kali menjadi stunting (Paudel et al, 2012). Penelitian di Kota Palembang tahun 2013 menyatakan bahwa balita yang tidak mendapatkan ASI secara Eksklusif mempunyai peluang sebanyak 4.010 kali status gizi anak balitanya stunted dibandingkan ibu-ibu yang memberikan ASInya secara Eksklusif. Unicef (2013), menyebutkan bahwa memberikan ASI Eksklusif kepada anak selama 6 bulan pertama dapat meningkatkan pencapaian pertumbuhan, perkembangan dan kesehatan yang optimal. Setelah itu dapat dilanjutkan dengan memberikan makanan pendamping ASI sampai umur 2 tahun atau lebih. ASI merupakan sumber alami yang memiliki dampak yang besar pada kesehatan, pertumbuhan dan perkembangan anak

ASI berisi semua zat-zat gizi yang dibutuhkan oleh bayi dalam jumlah yang cukup. Kandungan energi ASI berkisar 65 
$\mathrm{mg} / 100 \mathrm{ml}$ ASI, adapun kandungan protein dalam ASI 0,9 mg/100 ml ASI. Kandungan protein dalam ASI memang lebih rendah dibandingkan dengan kadar protein susu formula $(1,6 \mathrm{mg} / 100 \mathrm{ml})$, namun kualitas protein ASI sangat tinggi dan mengandung asam-asam amino esensial yang sangat dibutuhkan oleh pencernaan bayi (Widjaja, 2004). Keistimewaan protein ASI adalah rasio protein whey dan kasein yang seimbang (60 : 40), dibanding dengan susu sapi (20 : 80). Hal ini menguntungkan bayi karena pengendapan dari protein whey lebih halus dibanding kasein sehingga protein whey lebih mudah cerna (Roesli, 2001). Jika bayi lapar atau haus, dia akan menyusu lebih sering atau lama, hal ini akan merangsang hormon prolaktin untuk memproduksi ASI lebih banyak, sehingga kebutuhan optimal bayi untuk pertumbuhan tercukupi (Nugroho \& Sofyan , 2018).

\section{MP-ASI dini}

Hasil penelitian menyimpulkan tidak ada perbedaan pemberian MP-ASI dini pada anak stunting yang tinggal di desa dengan yang tinggal di perkotaan.

Pemberian makanan pre-lakteal menjadi faktor risiko yang signifikan terhadap stunting pada anak $0-23$ bulan $(\mathrm{OR}=1.47, \mathrm{p}<0.05)$. Penelitian Muchina dan Waithaka (2010), menunjukkan anak yang menerima makanan pre-lakteal lebih berisiko stunting $(\mathrm{OR}=1.80 ; \mathrm{p}<0.05)$. Susu formula adalah jenis makanan pre-lakteal yang paling banyak ditemui dalam penelitian ini (53\%). Keluarga yang memberikan pola asuh baik terutama terhadap kebutuhan zat gizi, maka akan mempengaruhi status gizi anak. Pemberian MP-ASI yang tepat pada anak usia 12-24 bulan akan menurunkan risiko malnutrisi, karena pada usia tersebut kebutuhan zat gizi anak tidak dapat tercukupi hanya dari ASI saja (Anugraheni \& Kartasurya, 2012).

MP-ASI berisi lebih banyak karbohidrat, dibanding ASI. Walaupun membuat kenyang, tapi tidak mengandung cukup zat-zat gizi yang dibutuhkan untuk pertumbuhan, terutama lemak dan protein, selain itu pemberian MP-ASI berkaitan dengan fungsi organ pencernaan. Semakin muda usia, maka organ pencernaan secara anatomis dan fisiologis belum berfungsi sempurna dan hanya dapat menampung dan mencerna sedikit makanan. Kecilnya daya cerna makanan, ditambah kandungan gizi yang tidak cukup, membuat bayi yang diberi MP-ASI pada usia yang lebih muda akan lebih rentan terhadap stunting.

Hasil penelitian di Kendari tahun 2016 menunjukkan bahwa proporsi balita stunting lebih banyak disebabkan oleh pemberian MP ASI pada usia $<6$ bulan di bandingkan pada balita yang tidak diberi MP ASI pada usia < 6 bulan. Pemberian MP-ASI terlalu dini meningkatkan risiko penyakit infeksi seperti diare karena MP- ASI yang diberikan tidak sebersih dan mudah dicerna seperti ASI. Selain pemberian MP-ASI yang terlalu dini, terlambatnya memberikan MP-ASI juga menyebabkan pertumbuhan dan perkembangan balita menjadi terhambat karena kebutuhan gizi balita tidak tercukupi (Jihad dkk, 2016). Penelitian ini sejalan dengan penelitian yang dilakukan Kadek (2012) yang menyatakan balita yang diberi MP ASI terlalu dini berisiko 6,3 kali menjadi stunting di bandingkan balita yang diberi MP ASI tepat waktu.

Faktor risiko stunting anak usia $0-23$ bulan di Bali, Jawa Barat, dan NTT adalah BBLR, tinggi badan ibu $<150 \mathrm{~cm}$, sanitasi kurang baik, dan pemberian makanan prelakteal (Nadiyah dkk, 2014).

\section{Sosial ekonomi}

Hasil penelitian menyimpulkan perbedaan sosial ekonomi keluarga pada anak stunting yang tinggal di desa dengan yang tinggal di perkotaan.

Balita yang berasal dari keluarga dengan status ekonomi rendah 1.29 kali berisiko mengalami stunting dibandingkan dengan balita dari keluarga dengan status ekonomi tinggi (Oktarina \& Sudiarti, 2013). Terdapat hubungan yang signifikan antara pendapatan keluarga dengan stunting pada anak $(\mathrm{p}<0.05)$. Terdapat hubungan yang positif dan signifikan antara pendapatan rendah dengan stunting pada anak usia $0-23$ bulan di Jawa Barat, Bali, dan NTT (Nadiyah dkk, 2014). 
Berdasarkan banyak penelitian, status ekonomi lebih banyak berpengaruh terhadap pertumbuhan linear dibandingkan pertumbuhan berat badan. Berdasarkan penelitian di kota palembang tahun 2013 sebagian besar anak stunting memiliki status sosek keluarga < UMR sebesar $51.6 \%$, dan diperoleh hubungan antara status sosial ekonomi keluarga dengan kejadian stunting. Penelitian di Nepal tahun 2012 menyatakan sosial ekonomi keluarga berhubungan dengan kejadian stunting dimana anak dengan sosial ekonomi menengah kebawah beresiko 3,11 kali menjadi stunting (Paudel et al, 2012). Faktor risiko kejadian stunting pada anak usia 12-24 bulan di Kecamatan Semarang Timur adalah status ekonomi keluarga rendah $(\mathrm{OR}=11.769)$ (Anshori \& Nuryanto, 2013). Status sosial ekonomi dipengaruhi pendidikan seseorang, yang akan berpengaruh terhadap peluang mendapatkan pekerjaan. Pekerjaan akan berpengaruh terhadap status ekonomi keluarga. Penelitian di Maluku pada anak usia 0-23 bulan dan penelitian di Bogor pada anak usia 6-12 bulan menunjukkan ada hubungan pendapatan keluarga dengan kejadian stunting (Anugraheni \& Kartasurya, 2012).

Keluarga dengan status ekonomi rendah akan mempunyai kesempatan untuk mencukupi kebutuhan pangan dan gizi keluarga yang rendah, sehingga anak lebih rentan terjadi stunting. Keluarga dengan status ekonomi tinggi memiliki kesempatan untuk memilih bahan makanan yang lebih bervariatif serta kebutuhan zat gizi tercukupi, sehingga risiko kejadian masalah gizi dapat ditekan. Hasil ini sesuai dengan penelitian di Maluku, bahwa keluarga dengan status ekonomi rendah merupakan faktor risiko kejadian stunting (Anugraheni \& Kartasurya, 2012).

Sosial ekonomi berhubungan erat dengan ketersediaan pangan keluarga, dimana ketersediaan pangan yang rendah mampu meningkatkan risiko 3,64 kali lebih besar untuk menghasilkan anak yang stunting dibandingkan dengan ketersediaan pangan keluarga yang baik. Rendahnya ketersediaan pangan, mengancam penurunan konsumsi makanan yang beragam dan bergizi seimbang dan aman di tingkat rumah tangga. Pada akhirnya, akan berdampak pada semakin beratnya masalah gizi masyarakat, termasuk stunting pada batita. Masalah akses dan ketersediaan pangan untuk penduduk miskin merupakan gabungan dari masalah kemiskinan, kurangnya pekerjaan tetap, pendapatan tunai rendah dan tidak tetap serta terbatasnya daya beli (BAPENAS, 2011).

Status ekonomi keluarga yang rendah akan mempengaruhi kualitas maupun kuantitas bahan makanan yang dikonsumsi oleh keluarga. Makanan yang didapat biasanya akan kurang bervariasi dan sedikit jumlahnya terutama pada bahan pangan yang berfungsi untuk pertumbuhan anak seperti sumber protein, vitamin dan mineral, sehingga meningkatkan risiko kurang gizi. Keterbatasan ini akan meningkatkan risiko terjadinya stunting pada anak balita. Berdasarkan hasil penelitian ini sosial ekonomi berhubungan dengan kejadian stunting sehingg perlu peran serta pemerintah daerah dalam peningkatan status sosial ekonomi yang berhubungan dengan kejadian stunting pada balita baik di pedesaan maupun perkotaan.

\section{KESIMPULAN}

Hasil penelitian menunjukkan bahwa ada perbedaan berat lahir, tinggi badan ibu dan sosial ekonomi balita stunting di pedesaan dan di perkotaan. Sedangkan untuk panjang badan lahir, ASI eksklusif dan MPASI dini tidak ada perbedaan antara di pedesaan dan di perkotaan.

Keseimpulan tersebut menyarankan agar kegiatan ANC dilakukan secara rutin oleh ibu hamil terkait dengan berat badan lahir yang berhubungan dengan kejadian stunting. Perlu ditingkatkan promosi pemberian ASI eksklusif dan MP ASI dini, oleh Puskesmas melalui penyuluhan sejak pemeriksaan kehamilan untuk mencegah kejadian Stunting pada anak usia 1- 5 tahun., Serta perlu peran serta pemerintah daerah dalam peningkatan status sosial ekonomi yang berhubungan dengan kejadian stunting baik di pedesaan dan perkotaan 


\section{DAFTAR PUSTAKA}

Anugraheni, HS \& Kartasurya, MI. (2012). Faktor risiko kejadian stunting pada anak usia 12-36 bulan di Kecamatan Pati, Kabupaten Pati. Eprints Undip.

BAPENAS. (2011). Rencana Aksi Nasional Pangan dan Gizi 2011-2015. BAPENAS: Jakarta.

Candra A, Puruhita N, Susanto JC. (2011). Risk Factors of Stunting among 1-2 Years Old Children in Semarang City. Media Medika Indonesia. 45: 206-212.

Dewey KG. (2012). Technical Meeting on The Long-term Consequences of Chronic Undernutrition in Early Life. Unicef; August 2012, New York [cited June 3, 2017]. Download from http://cdn.livestream.com/events/unicef 1/6_Dewey_Session4_Programming_R evised.pdf

Horta BL, Bahl R, Martines JC, Victoria CG. (2007). Evidence on the long-term effects of breastfeeding. WHO: Geneva, Switzerland.

Husein Al-Anshori \& Nuryanto. (2013). Faktor Risiko Kejadian Stunting Pada Anak Usia 12-24 Bulan (Studi Di Kecamatan Semarang Timur). Eprints Undip.

Janirah Jihad, Ode Ali Imran Ahmad, Ainurafiq. (2016). Analisis determinan kejadian stunting pada balita usia 1224 bulan Di wilayah kerja puskesmas puuwatu kota kendari tahun 2016. Fakultas Kesehatan Masyarakat Universitas Halu Oleo.

Kemenkes. (2010). SK Menkes 2010 tentang Standar Antropometri Penilaian Status Gizi Anak. Direktorat Jenderal Bina Gizi dan Kesehatan Ibu dan Anak. Direktorat Bina Gizi: Jakarta.

Kementerian Kesehatan RI. (2013). Laporan Riset Kesehatan Dasar 2013. Kemenkes: Jakarta.

Kiely JL, Yu S, Rowley DL. (2013). Low Birth weight and intrauterine growth retardation. CDC public health surveillance for women, infants and children. [serial online] [cited 2013 March 12th] Available from: URL: http://www.cdc.gov/
Kusharisupeni. (2003). Peran status kelahiran terhadap stunting pada bayi : sebuah studi prospektif. J Kedokter Trisakti. 23.

Muchina \& Waithaka (2010). Relationship between breastfeeding practices and nutritional status of children aged 0-24 months in Nairobi, Kenya. African Journal of Food, Agriculture, Nutrition and Development. 10.

Nadiyah, Briawan dan Martianto. (2014). Faktor risiko stunting pada anak usia 0-23 bulan Di provinsi bali, jawa barat, dan nusa tenggara timur . Jurnal Gizi dan Pangan. 9: 125-132.

Nasikhah, R. (2012). Faktor Risiko Kejadian Stunting Pada Balita Usia 24-36 Bulan di Kecamatan Semarang Timur. Program Studi Ilmu Gizi Fakultas Kedokteran Universitas Diponegoro. Semarang.

Nugroho, A, \& Musabiq, S. (2018). Gizi 1000 HPK. CV Anugrah Utama Raharja: Bandar Lampung.

Nugroho, A, (2016). Growth Failure (Stunting) pada anak umur $1 \mathrm{~s} / \mathrm{d} 3$ tahun yang lahir dengan berat badan normal di Kecamatan Tanjungkarang Barat Kota Bandar Lampung. Jurnal Kesehatan. 7.

Oktarina, Z \& Sudiarti, T. (2013). Faktor risiko stunting pada balita (24-59 bulan) di sumatera. Jurnal Gizi dan Pangan. 8(3): 175-180.

Paudel, R; Pradhan, B; Wagle, RR; Pahari, DP; Onta, SR. (2012). Risk Factors for Stunting Among Children: A Community Based Case Control Study in Nepal. Kathmandu University Medical Journal. 10

Rahayu, L.S \& Sofyaningsih, M. (2011). Pengaruh BBLR (Berat Badan Lahir Rendah) dan Pemberian ASI Eksklusif Terhadap Perubahan Status Stunting Pada Balita di Kota dan Kabupaten Tangerang Provinsi Banten. Jurnal Proseding Nasional "Peran Kesehatan Masyarakat dalam Pencapaian MDG's di Indonesia". 
Renyoet, BS; Martianto, D \& Sukandar, D. (2013). Potensi kerugian ekonomi karena stunting pada balita Di indonesia tahun 2013. J. Gizi Pangan, 11.

Supartini, Y. (2004). Buku ajar konsep dasar keperawatan anak. EGC: Jakarta.

Susilowati; Kusharisupeni; Fikawati, S, \& Achmad, K. (2010). Breast feeding duration and children's nutritional status at age 12-24 months. Paediatrica Indonesiana. 50(1): 56-61.
Taguri, A.E; Ibrahim, B; Salah, M.M; Abdel M.A; Oliver, G; Pilar, G \& Serge, H. (2008). Risk factors for stunting among under-fives in Libya. Public Health Nutrition. 12(8): 1411-1149.

UNICEF. (2013). Report Improving Child Nutrition: The Achievable imperative for global progress. UNICEF: Genewa. WHO. (2016). WHA Global Nutrition Targets 2025: Stunting Policy Brief. WHO: Genewa. 